\title{
Association between Psoriasis and Obesity
}

\author{
Pandey $\mathrm{S}^{1}$, Jha $\mathrm{S}^{2}, \mathrm{BK} \mathrm{S}^{3}$, Pokharel $\mathrm{K}^{4}$
}

\begin{abstract}
Background: Psoriasis is primarily a chronic skin disease, the course being punctuated by remissions and relapses. Research has shown that hypertension, obesity, heart failure and diabetes are significantly more common in patients with psoriasis. Obesity is associated with severe psoriasis and is reported about twice as frequently among psoriasis patients as in the general population. In recent years many reports have demonstrated an association between psoriasis and metabolic syndrome. Objectives: The aim of this study was to identify the prevalence of obesity in patients with psoriasis and compare it with that of non-psoriatic population. Material and Method: This study is a case control hospital based study conducted in the Department of Dermatology, Venereology and Leprology of Nepalgunj Medical College Teaching Hospital, Kohalpur between May 2017 to October 2018.Total 56 cases of psoriasis and similar number of healthy age and sex matched controls were enrolled in the study after taking written consent. Detailed history and physical examination was performed with measurement of body mass index which was recorded. Statistical analysis was done using SPSS 20. Result: The results of the study which included 56 patients with psoriasis and 56 subjects without psoriasis. Among them 26 male and 30 female in study population and 25 male and 31 female in control group. The mean age was $41.68 \pm 19.04$ years in study population and $39.46 \pm 16.27$ years in control group. Duration of disease ranged from 2 months to 360 months and PASI score ranged from 4.4 to 28.2 with mean PASI score $11.02 \pm 5.4$. BMI in cases ranged from 16.7 to 34.2 with mean $24.3 \pm 4.3$ and in controls it ranged from 15.5 to 29.1 with mean $21.9 \pm 3$. Mean BMI was significantly higher in cases than controls. Conclusion: The result of this study supports the significantly higher prevalence of obesity in study population than control group.
\end{abstract}

Keywords: Psoriasis, obesity

\section{INTRODUCTION}

Psoriasis is a common skin disorder affecting approximately 1$6 \%$ of the population in the world. Psoriasis is a chronic skin disease characterized by inflammatory cell infiltration, hyper proliferation of epidermal cells and dilated microvessels ${ }^{1}$. Studies suggest that the disease has bimodal onset, the first peak at the age between $16-22$ years and later at $57-60$ years of age $^{2}$. Psoriasis tends to occur equally in both the sexes. studies have shown that the mean age of onset is at 33 years of age and $75 \%$ of cases occurs before the age of 46 years ${ }^{3}$.

The etiopathogenesis of psoriasis is not well understood and various etiological factors have been thought to cause the disease in combination including genetic factors, trauma, infection, environmental factors, drugs, endocrine factors, sunlight, metabolic factors, alcohol, cigarette, and psychological factors ${ }^{4}$. It is characterized by exaggerated and disordered epidermal cell proliferation and keratinization. A host of abnormalities seen in psoriasis, like increased levels of

1. Dr. Sumit Pandey

2. Dr. Smita Jha

3. Dr. Shyam Kumar B.K

4. Dr. Kumar Pokharel

Address for correspondence:

Dr. Sumit Pandey

Department of Dermatology

Nepalgunj Medical College \& Teaching Hospital

Kohalpur, Banke, Nepal

Email: sumitpandey207@yahoo.com cyclic - adenosine monophosphate (CAMP), epidermal growth factor receptor binding, protein kinase $\mathrm{C}$ and transforming growth factors collectively point to a disturbance in $\mathrm{T}$ cell function. Currently, the most accepted hypothesis is that psoriasis is an immune-mediated inflammatory skin disease that manifests in a genetically predisposed person exposed to certain environmental agents or triggers. This view has been reinforced by the efficacy of various immunomodulatory agents in the treatment of psoriasis ${ }^{5}$.

Obesity is associated with severe psoriasis and is reported about twice as frequently among psoriasis patients as in the general population. In recent years many reports have demonstrated an association between psoriasis and metabolic syndrome. Metabolic syndrome is combination of: Central obesity, diabetes mellitus type 2, hypertension and dyslipidaemia ${ }^{6}$.

There are several evidences which indicate that psoriasis is closely associated with obesity and hypertension. Herron et al. found that obesity is almost twice as prevalent in patients with psoriasis as in general population. ${ }^{7}$

\section{METHODS}

This study is a hospital based Case control study conducted in the Department of Dermatology Venereology \& Leprology, Nepalgunj Medical College Teaching Hospital Kohalpur, between May 2017 to October 2018. Before initiating the study the proposal of the study was submitted to the Institutional Review Board. The study population included the patients 
visiting the OPD of Department of Dermatology, Venereology and Leprology of NGMCTH who were diagnosed as having psoriasis either on the clinical ground and/or histopathologically.

\section{Inclusion criteria included}

Case:

a) Clinically and/or histopathologically diagnosed cases of psoriasis by a dermatology consultant.

b) Age > 16years, belonging to either gender.

\section{Control}

a) Age and sex matched healthy adult population who were hospital staff or attendants of the patients.

b) More than 16 years age, belonging to either gender.

c) No evidence of psoriasis or any other systemic illness.

Altogether 112 (both case and control) patients were included in the study. Diagnosis of psoriasis was made clinically by the consultant dermatologist. The PASI score, BMI were calculated by the author himself. The will of the subjects was fully respected and those who did not give consent for participation were excluded from the study. A written consent was taken from each patient after explaining the relevant details of the study, its importance and implications. Confidentiality was maintained to utmost. Detailed history was taken and detailed clinical examination and investigation was performed and the details were recorded. Statistical analysis was done using SPSS 20. Fisher's exact test was used for significance testing and $P$ value less than 0.05 was considered significant. Odds ratio was used to compare the risk between cases and controls.

\section{RESULTS}

A total of 56 cases were included in the study. Fifty six age and sex matched controls were also enrolled. Age of the cases ranged from 18 to 82 years with the mean age $41.68 \pm 19.04$ years. Age of the controls ranged from 19 to 92 years with mean age $39.46 \pm 16.27$ years. There was no significant difference in age distribution of cases and controls across the groups ( $P$ value $=0.796)$ as shown in figure 1 .

\section{Gender distribution}

Out of 56 cases, 26 (46.6\%) were male and 30 (53.6\%) were female. Out of 56 controls, 25 (44.6) were male and 31 (55.4\%) were female as shown in figure 2 . There was no significant difference in proportion of male and female between cases and controls ( $P$ value $=1$ ).

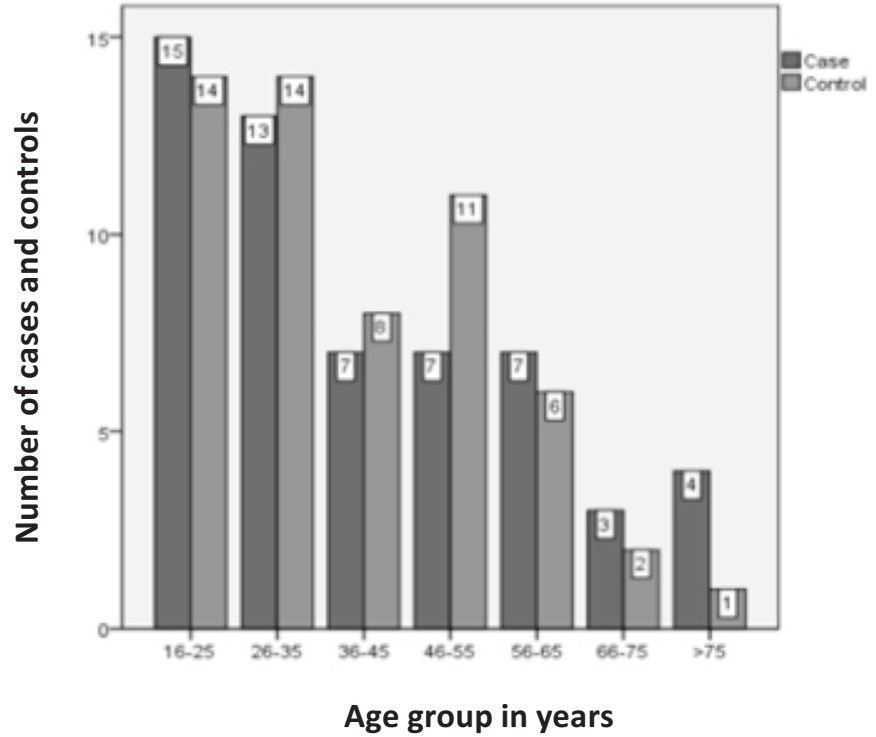

Figure 1: Age distribution of cases and controls

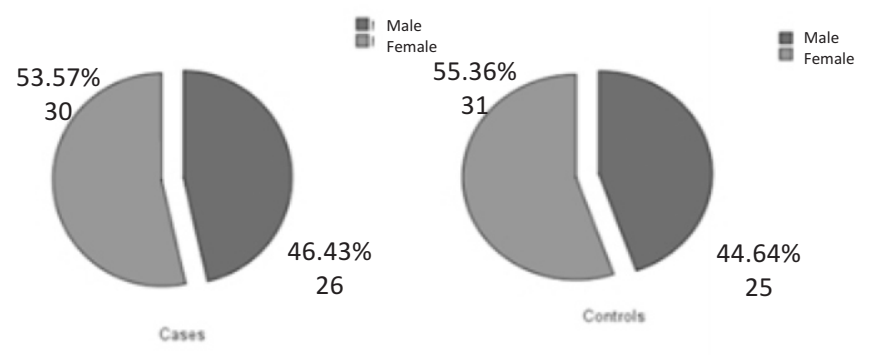

Figure 2: Gender Distribution

\section{Duration of disease}

Duration of disease ranged from 2 months to 360 months with mean duration of $72.21 \pm 67.23$ months as shown in table I below.

\begin{tabular}{|l|c|c|}
\hline $\begin{array}{l}\text { Duration of } \\
\text { psoriasis }\end{array}$ & $\begin{array}{c}\text { Numbers of } \\
\text { patients }(\mathbf{n = 5 6})\end{array}$ & Percentage \\
\hline$<1$ year & 4 & 7.1 \\
\hline $1-<5$ years & 24 & 42.9 \\
\hline $5-<10$ years & 15 & 26.8 \\
\hline$\geq 10$ years & 13 & 23.2 \\
\hline
\end{tabular}

Table I

\section{Severity of the disease (PASI)}

PASI score ranged from 4.4 to 28.2 with mean PASI score 11.02 \pm 5.4 .

\section{BMI (in $\mathrm{kg} / \mathrm{m}^{2}$ )}

$\mathrm{BMI}$ in cases ranged from 16.7 to 34.2 with mean $24.3 \pm 4.3$ and in controls it ranged from 15.5 to 29.1 with mean $21.9 \pm 3$. Mean BMI was significantly higher in cases than controls with $p$ value $=0.001$ shown in table II. 


\begin{tabular}{|l|c|c|c|}
\hline Classification & BMI (Kg/m2) & Cases & Control \\
\hline Underweight & $<18.5$ & 3 & 7 \\
\hline Normal range & $18.5-24.9$ & 32 & 39 \\
\hline Pre-obese & $25-29.9$ & 13 & 10 \\
\hline Obsese I & $30-34.9$ & 8 & - \\
\hline Obese II & $35-39.9$ & - & - \\
\hline Obese III & $\geq 40$ & - & - \\
\hline
\end{tabular}

Table II: Number of cases and controls according to WHO (2000) classificationfor BMI

Prevalence of high BMI $\left(\geq 25 \mathrm{~kg} / \mathrm{m}^{2}\right)$ in cases and controls Prevalence of $\mathrm{BMI} \geq 25 \mathrm{~kg} / \mathrm{m}^{2}$ was significantly higher in psoriatic patients than controls (Table III). Psoriatic patients had 2.8 times increased odds of getting high BMI than controls.

\begin{tabular}{|l|c|c|c|l|}
\hline & Cases & Controls & $\begin{array}{c}\text { Odds } \\
\text { Ratio }\end{array}$ & P value \\
\hline BMI $\geq 25 \mathrm{~kg} / \mathrm{m}^{2}$ & $21(37.5 \%)$ & $10(17.9 \%)$ & $\begin{array}{c}2.8(95 \% \\
\text { Cl } 1.2-6.6)\end{array}$ & \\
\hline BMI $\leq 25 \mathrm{~kg} / \mathrm{m}^{2}$ & $35(62.5 \%)$ & $46(82.1 \%)$ & & \\
\hline
\end{tabular}

Table III: Comparison of prevalence of high BMI in cases and controls

\begin{tabular}{|c|c|c|}
\hline BMI & Mean PASI \pm SD & P value \\
\hline $\mathrm{BMI} \geq 25 \mathrm{~kg} / \mathrm{m}^{2}$ & $11.2 \pm 6.0$ & 0.742 \\
\hline $\mathrm{BMI}<25 \mathrm{~kg} / \mathrm{m}^{2}$ & $10.7 \pm 4.3$ & \\
\hline
\end{tabular}

Table IV: Association of BMI disease severity (PASI)

\section{Association of $\mathrm{BMI}$ and disease duration}

Mean values of disease duration (in months) in psoriatic patients were compared between the groups with $\mathrm{BMI}<25$ $\mathrm{kg} / \mathrm{m}^{2}$ and $\mathrm{BMI} \geq 25 \mathrm{~kg} / \mathrm{m}^{2}$. There was no significant difference in mean disease duration between the groups which is shown in table $\mathrm{V}$.

\begin{tabular}{|c|c|c|}
\hline BMI & $\begin{array}{c}\text { Mean duration of } \\
\text { disease } \\
\text { (in months)) } \pm \text { SD }\end{array}$ & P value \\
\hline $\mathrm{BMI} \geq 25 \mathrm{~kg} / \mathrm{m}^{2}$ & $69.7 \pm 73.9$ & 0.71 \\
\hline $\mathrm{BMI}<25 \mathrm{~kg} / \mathrm{m}^{2}$ & $76.5 \pm 55.6$ & \\
\hline
\end{tabular}

Table V: Association of BMI and disease duration

\section{DISCUSSION}

There have been many studies linking psoriasis to the individual components of the metabolic syndrome since many years ${ }^{8,9}$. A total of 56 cases and age and sex matched 56 controls were enrolled in this study. Age of the psoriatic patients ranged from 18 to 82 years with mean age $41.68 \pm 19.04$ years and maximum number of patients were of age group 16 to 35 years, which was similar to the study done at TUTH by Shrestha et $\mathrm{al}^{10}$. There were slightly higher proportions of female $(53.6 \%)$ than male $(46.6 \%)$ in this study but the study done by Shrestha et al ${ }^{10}$ showed slightly higher proportion of male $(51.7 \%)$ than female (48.3\%) however the difference was not statistically significant.

In this study, Duration of disease ranged from 2 months to 360 months with mean duration of $72.21 \pm 67.23$ months which was similar to study done by Lakshmi et al171, Madanagobalane et $\mathrm{al}^{11}$ and Gisondi et $\mathrm{al}^{12}$. In this study PASI score ranged from 4.4 to 28.2 with mean PASI score $11.02 \pm 5.4$ which is similar to study done by Lakshmi et a $\left.\right|^{13}$ Madanagobalane et $\left.a\right|^{11}$.

In this study, prevalence of obesity (i.e. BMI $\geq 25 \mathrm{~kg} / \mathrm{m}^{2}$ ) was significantly higher in psoriatic patients $(37.5 \%)$ than controls (17.9\%) ( $P=0.034)$. Psoriatic patients had 2.8 times increased odds of getting high BMI than controls. Similar result was seen in study done by Gisondi et al ${ }^{12}$ Kaye et al ${ }^{14}$.

There was no significant difference in the mean PASI score between the groups having $\mathrm{BMI} \geq 25 \mathrm{~kg} / \mathrm{m}^{2}$ and $\mathrm{BMI}<25 \mathrm{~kg} / \mathrm{m}^{2}$. Similar results were seen in study done by Gisondi et $\mathrm{a}^{12}$ and Lakshmi et $\mathrm{al}^{13}$.

There was no significant difference in the mean disease duration between the groups having BMI $\geq 25 \mathrm{~kg} / \mathrm{m}^{2}$ and $\mathrm{BMI}<25 \mathrm{~kg} / \mathrm{m}^{2}$. Similar results were seen in the study done by Madanagobalane et $\mathrm{al}^{11}$ and Baeta et $\mathrm{al}^{15} \mathrm{However}$, the study done by Mallbris et $\mathrm{al}^{16}$ and Nisa et $\mathrm{al}^{17}$ had shown positive association between disease duration and BMI.

\section{CONCLUSION}

Psoriasis is one of the chronic inflammatory skin diseases, affecting mostly young adults. Different studies have shown its is association with higher prevalence of metabolic syndrome. This study also supports the finding of significantly higher prevalence of obesity in psoriatic patients than control group. Thus, psoriasis should not be regarded as a simple skin disease but rather as a systemic inflammatory disease. The knowledge that psoriasis can be associated with obesity can make dermatologist to screen the psoriatic patient early for obesity and patients can be advised about adapting healthy lifestyle, including diet and exercise.

\section{Limitation of the study}

The sample size was small to draw the valid inferences to the larger population

\section{REFERENCES}

1. Myers W, Opeola M, Gottlieb AB. Common clinical features and disease mechanisms of psoriasis and psoriatic arthritis. Current rheumatology reports. 2004 Aug;6(4):306-13.

2. Golpour M, Hosseini SH, Khademloo M, Ghasemi M, Ebadi A, Koohkan $\mathrm{F}$, et al. Depression and Anxiety Disorders among Patients with 
Psoriasis: A Hospital-Based Case-Control Study. Dermatology research and practice. 2012;2012:381905.

3. Henseler T, Christophers E. Psoriasis of early and late onset: characterization of two types of psoriasis vulgaris. Journal of the American Academy of Dermatology. 1985 Sep;132:450-6.

4. Brandrup F, Green A. The prevalence of psoriasis in Denmark. Acta dermatovenereologica. 1981;61(4):344-6.

5. Winterfield LS, Menter A, Gordon K, Gottlieb A. Psoriasis treatment: current and emerging directed therapies. Annals of the rheumatic diseases. 2005 Mar;64 Suppl 2:ii87-90; discussion ii1-2.

6. Naldi L, Chatenoud L, Linder D, Belloni Fortina A, Peserico A, Virgili $A R$, et al. Cigarette smoking, body mass index, and stressful life events as risk factors for psoriasis: results from an Italian casecontrol study. The Journal of investigative dermatology. 2005 Jul;125(1):61-7.

7. Neimann AL, Shin DB, Wang X, Margolis DJ, Troxel AB, Gelfand JM. Prevalence of cardiovascular risk factors in patients with psoriasis. Journal of the American Academy of Dermatology. 2006 Nov;55(5):829-35.

8. Sommer DM, Jenisch S, Suchan M, Christophers E, Weichenthal $M$. Increased prevalence of the metabolic syndrome in patients with moderate to severe psoriasis. Archives of dermatological research. 2006 Dec;298(7):321-8.

9. Sterry W, Strober BE, Menter A, International Psoriasis C. Obesity in psoriasis: the metabolic, clinical and therapeutic implications. Report of an interdisciplinary conference and review. The British journal of dermatology. 2007 Oct;157(4):649-55.

10. D.P S, D G. Psoriasis:Clinical and epidemiological features in a hospital based study. NJDVL. 2012;10(1):41-5.

11. Madanagobalane S, Anandan S. Prevalence of metabolic syndrome in South Indian patients with psoriasis vulgaris and the relation between disease severity and metabolic syndrome: a hospital-based case-control study. Indian journal of dermatology. 2012 Sep;57(5):353-7.

12. Gisondi P, Tessari G, Conti A, Piaserico S, Schianchi S, Peserico A, et al. Prevalence of metabolic syndrome in patients with psoriasis: a hospital-based case-control study. The British journal of dermatology. 2007 Jul;157(1):68-73.

13. Lakshmi S, Nath AK, Udayashankar C. Metabolic syndrome in patients with psoriasis: A comparative study. Indian dermatology online journal. 2014 Apr;5(2):132-7.

14. Kaye JA, Li L, Jick SS. Incidence of risk factors for myocardial infarction and other vascular diseases in patients with psoriasis. The British journal of dermatology. 2008 Sep;159(4):895-902.

15. Baeta IG, Bittencourt FV, Gontijo B, Goulart EM. Comorbidities and cardiovascular risk factors in patients with psoriasis. Anais brasileiros de dermatologia. 2014 Sep-Oct;89(5):735-44.

16. Mallbris L, Granath F, Hamsten A, Stahle M. Psoriasis is associated with lipid abnormalities at the onset of skin disease. Journal of the American Academy of Dermatology. 2006 Apr;54(4):614-21.

17. Nisa N, Qazi MA. Prevalence of metabolic syndrome in patients with psoriasis. Indian journal of dermatology, venereology and leprology. 2010 Nov-Dec;76(6):662-5. 